Volume and Issues Obtainable at Center for Sustainability Research and Consultancy

Journal of Accounting and Finance in Emerging Economies

ISSN: 2519-0318 \& ISSN (E): 2518-8488

Volume 7: Issue 4 December 2021

Journal homepage: www.publishing.globalcsrc.org/jafee

\title{
Determinants of Militancy and its Effects on Education in Districts Mohmand of Khyber Pakhtunkhwa, Pakistan
}

*Alamzeb Khan, Ph.D. Research Scholar, Department of Rural Development, Institute of Development Studies, The University of Agriculture, Peshawar, Pakistan

Naushad Khan, Assistant Professor, Department of Rural Development, Institute of Development Studies, The University of Agriculture, Peshawar, Pakistan

*Corresponding author's email: alamzebrd@gmail.com

\begin{tabular}{l}
\hline ARTICLE DETAILS \\
\hline History \\
Revised format: Nov 2021 \\
Available Online: Dec 2021 \\
\hline Keywords \\
Militancy, Drop out, \\
Education, Early marriage, \\
family size, Distance from \\
School \\
JEL Classification \\
$C 1, C 5, K 1, K 5$
\end{tabular}

Purpose: The main objective of this study is to investigate the determinants of militancy and its effect on education in terms of students' dropout in District Mohmand of Khyber Pakhtunkhwa, Pakistan, in 2018-19.

Methodology: The review depends on essential information and a sum of 358 families has been acquired through the Yamane Formula. The information has been investigated through the ChiSquare test just as the Multiple Linear Regression Model by means of SPSS programming.

Findings: The chi-square experimental outcome observed a critical relationship between understudies exiting and diverse financial variables, to be specific militancy, pay, early marriage, family size, schooling, and family framework. The impact of militancy was additionally seen after disaggregation of information into male and female and revealed a high impact in females contrasted with their male partners. Assessed relapse examination shows that understudy dropout is emphatically connected with the distance of respondents' homes to the nearest school, family size, militancy and family system.

Implications: The review prescribes that the public authority needs to control the Pak-Afghan line and spotlight on the decrease of destitution, work on the monetary turn of events, and increment the instructive spending plan

(C) 2021, The authors, under a Creative Commons AttributionNonCommercial 4.0

Recommended citation: Khan, A., \& Khan, N., (2021). Determinants of Militancy and its effects on Education in Districts Mohmand of Khyber Pakhtunkhwa, Pakistan. Journal of Accounting and Finance in Emerging Economies, 7(4), 969-978

\section{Introduction}

Militancy indicates a development where a group of people is occupied in the equipped battle to accomplish a target and subsequently hold a forceful disposition supporting a demeanor or cause 
(Antonio Casses, 2006). Pakistan faces extensive instructive issues, including restricted admittance, lower education rates, and enormous provincial contrasts. Orientation separation, absence of gifted educators, and terrible school framework are only a couple of the critical purposes behind the country's poor instructive status (Shabir Hyder, Naeem Akram, and Ihtsham Ul Haq Padda, 2015; Ullah \& Muhammad, 2020). Pakistan is one of the creating scene countries confronting genuine aggressiveness chances. The nation has seen numerous sorts of aggressiveness. Revolutionary gatherings utilize various methodologies to scare society to authorize their plan (Rizvi, 2005). The recently blended regions Ex. FATA individuals are the ones who stand the weight of the contention in the district. The militant has mercilessly butchered many individuals, including ladies and kids. Schools were exploded, and ancestral seniors were unpredictably focused on (Ahmad et al., 2012). The nearby individuals have been driven away from their homes. Security powers are handling the danger and forfeiting their lives in a recently consolidated locale to resuscitate the instructive framework. The assailants were prohibiting schooling nearby, especially female training in the region (Ali, 2008).

The absence of admittance to quality schooling brings about provincial masses being poor in usefulness. Instructive administrations in rustic and metropolitan regions are generally isolated. To accomplish a huge extent of the provincial populace to add to a country's financial development and for the rustic populace to have equivalent open doors for quality instruction (Maxwell et al., 2001). Instruction in real essence frees a general public from odd notions, ingraining practical people's mentality and answers for the advanced world. Instructive professionals focused on the significance of cultivating the voices of helpless pieces of society that could guarantee their incorporation into standard schooling (Vanessa Andreotti and Mario T. M. de Souza 2008). The overview was led mutually by UNICEF and the Government of Pakistan in 2000, and they characterized dropout as the withdrawal of youngsters from school at any level prior to finishing essential training. They proceed to say that "nonconformist" is an expression used to depict students who leave school prior to finishing a predefined level of instruction for reasons unknown (Umoh, 1986). After reliable assaults, numerous kids were rejected by their folks from schools. The instruction foundation was shut for one to two years on account of the assailant bunch. Afghan Commission for Human Rights reports that in 2006-2008 the number of understudies diminished, i.e., simply 10.52 percent for young ladies and 8.0 percent for young men going to the schools. The high uncertainty and understudies were straightforwardly connected with exceptionally perilous conditions. In excess of 40,000 youngsters were being taboo from schools toward the finish of 2009 because of assaults on training foundations and the annihilation of schools.

The research gap of this study is that no specific work has been done to decide the impact of militancy and other financial determinants on student dropout in district Mohmand. The major objective of this study is to explore the determinants of militancy and its effect on education in terms of students' dropping out in the study area.

\section{Materials and Methods \\ Universe of the Study}

The Province Khyber Pakhtunkhwa of Pakistan by and large and recent Ex. FATA organizations which are presently recently blended Khyber Pakhtunkhwa regions were extensively impacted by the twisting of aggressiveness. Enormous scope pulverization occurred in many pieces of Khyber Pakhtunkhwa. Keeping in view, the need to cover the reasons for aggressiveness and its impact based on instruction in more extensive conditions, the current review inspected reasons for militancy and its impact on schooling in ancestral region Mohmand. All the current seven tehsils of locale Mohmand comprise the universe of the review. The principal purpose for the determination of this region is that numerous instructive organizations were impacted during the twisting of militancy in region Mohmand. 


\section{Sampling Procedure}

The current review took on multi-stage inspecting. In the primary stage, District Mohmand was chosen. In the subsequent stage, three tehsils, to be specific tehsil Safi, Halimzai, and Yaka Ghund among seven tehsils were chosen in the review region. In the third stage, two towns were haphazardly chosen from each tehsil, be specific Masood and Gurbaz from tehsil Safi, Sultan Khel, and Baro Khel from Halimizai and Aqra Dag and Sroo Kaly were chosen from Yaka Ghund in the review region. In the fourth stage, various families were arbitrarily chosen from chosen towns in the review region for information assortment.

\section{Sample Size}

The absolute family number in the chosen towns of region Mohmand was 3477 . Yamane equation (1967). The room forgiving and take was 0.05. The Formula is given beneath:

$$
\mathrm{n}=\frac{\mathrm{N}}{1+\mathrm{N}(\mathrm{e})^{2}}
$$

Yamane (1967). Issues to Accompany Statistics: An Introduction Analysis. Harper and Row. Where $\mathrm{n}$ is the example size, $\mathrm{N}$ is the absolute populace size, and e is the mistake level of accuracy. Placing the given qualities in the above equation, the example size was assessed.

$$
\mathrm{n}=\frac{3477}{1+3477(0.05)^{2}}=358
$$

In the wake of assessing test size, the corresponding designation technique was utilized to additionally circulate test size among the chosen towns.

The extent designation recipe is composed as:

$$
\mathrm{n}_{\mathrm{i}}=\frac{\mathrm{N}_{\mathrm{i}}}{\mathrm{N}} \times \mathrm{n}
$$

Where:

$\mathrm{N}=$ Total Population of sampled respondents.

$\mathrm{Ni}=$ Total population of respondents in each selected village.

$\mathrm{n}=$ Total number of respondents selected in the study area.

$\mathrm{ni}=$ Total number of sampled respondents from each village.

Table 1: Total and sample from selected households in the study area.

Table 1: Total and Test from Chosen Families in the Review Region

\begin{tabular}{lll}
\hline Name of selected villages & Number of households & Sample \\
\hline Masood & 298 & 30 \\
Gurbaz & 378 & 38 \\
Sultan Khel & 237 & 24 \\
Baro Khel & 1431 & 143 \\
Aqra Dag & 532 & 53 \\
Sroo Kaly & 601 & 70 \\
\hline Total & 3477 & 358 \\
\hline
\end{tabular}

Source: Survey (2018) 


\section{Multiple Linear Regression Model and its Specification}

The numerous Linear Regression Model was applied in this review. Its shows the connection between the reliant variable (Student Dropout) and informative factors i.e Income of family head, training of family head, Distant of the respondent to the closest school, Family size, Militancy, Early marriage, Gender of Household Head, and Family System. The review was guided with the objective to break down the impact of militancy on instruction. Saqib and Ahmad (2014) were taken on for dissecting the impact of aggressiveness on instruction.

The general form of the model as;

$$
Y=f\left(X_{1}+X_{2}+X_{3}+X_{4}+U i\right.
$$

The above functional form can be specifically written as below;

$$
Y_{i}=\beta_{0}+\beta_{1} X_{1}+\beta_{2} X_{2}+\beta_{3} X_{3}+\beta_{4} X_{4}+\beta_{5} D_{1}+\beta_{6} D_{2}+\beta_{7} D_{3}+\beta_{8} D_{4}+\varepsilon_{i} \ldots
$$

\begin{tabular}{|c|c|c|}
\hline$Y_{i}$ & $=$ & Number of students dropped out from school \\
\hline $\mathrm{X}_{1}$ & $=$ & Income of household (Rs monthly) \\
\hline $\mathrm{X}_{2}$ & $=$ & Education of household head (in Years) \\
\hline $\mathrm{X}_{3}$ & $=$ & Distance of respondent's home to nearest school (in Km) \\
\hline $\mathrm{X}_{4}$ & $=$ & Household size (in Numbers) \\
\hline $\mathrm{D}_{1}$ & $=$ & $\begin{array}{l}\text { Militancy, }\left(D_{1}=1 \text {, if any household members dropout from }\right. \\
\text { School, due to any type of militant activity, } 0 \text { otherwise })\end{array}$ \\
\hline $\mathrm{D}_{2}$ & $=$ & $\begin{array}{l}\text { Early marriage, }\left(D_{1}=1 \text {, if household members dropout from }\right. \\
\text { School due to early marriage system, } 0 \text { otherwise })\end{array}$ \\
\hline $\begin{array}{l}\mathrm{D}_{3} \\
\text { ise) }\end{array}$ & $=$ & Gender of the Household head $\left(D_{1}=1\right.$, if household head is male, 0 \\
\hline $\mathrm{D}_{4}$ & $=$ & Family system, $\left(D_{1}=1\right.$, if joint and, 0 otherwise $)$ \\
\hline $\boldsymbol{\varepsilon} \mathbf{i}$ & $=$ & s the random variable which consists of those factors \\
\hline
\end{tabular}

Where,

(Other than variables considered) which affect the dependent variable.

\section{Results and Discussion}

This part is connected Chi-square test and Multiple Leaner Regression Model, which was assessed to decide the impact of militancy and other financial determinants on understudies exited in the review region.

Table 2: Association between Students Drops Out with Different Variables in the Study Area

\begin{tabular}{llllll}
\hline $\begin{array}{l}\text { Independent } \\
\text { variable }\end{array}$ & $\begin{array}{l}\text { Dependent } \\
\text { variables }\end{array}$ & $\begin{array}{l}\text { Chi- square } \\
\text { value }\end{array}$ & P -value & Gamma & P-value \\
\hline Militancy & Students Dropout & 70.538 & .000 & .762 & .000 \\
Income & Students Dropout & 91.484 & .000 & -.686 & .000 \\
Early marriage & Students Dropout & 15.026 & .001 & .399 & .000 \\
Family Size & Students Dropout & 48.356 & .000 & .224 & .002 \\
Distance & Students Dropout & 54.959 & .000 & .485 & .000 \\
\hline
\end{tabular}




\begin{tabular}{llcccc}
\hline Education & Students Dropout & 40.473 & .001 & -.450 & .000 \\
Family system & Students Dropout & 24.361 & .000 & .506 & .000 \\
\hline
\end{tabular}

\section{Source: Field Survey, 2019}

\section{Association between Students Drops Out with Different Variables in the Study Area}

The Chi-Square Test of Independence investigates whether absolute factors are related (i.e., regardless of whether the factors are free or related). It is a nonparametric test. Table 1 shows the relationship among aggressiveness and other financial determinates on understudy dropout in the review region. Results uncover that free factors like hostility, early relationships, family size, distance, and the family framework had a p-esteem is 0.000 which is under 0.05 , and its shows a profoundly huge relationship between the reliant and autonomous factors and gamma shows a positive heading. Notwithstanding, the relationship among pay and schooling of the family head was likewise seen as critical with a p-worth of 0.001 which is under 0.05 and gamma shows a backward bearing. The accompanying outcome is with the line (Christine et al., 2007). The ChiSquare test uncovered a connection between destitution, an association of young ladies' kids in housework/cultivating, strict training of young ladies, early relationships of female understudies, absence of kids' advantage, hostility, and elementary school dropout of young ladies' understudies.

Table 3: Effect of Militancy on Male Students Dropout in the Study Area

\begin{tabular}{lllll}
\hline Militancy & \multicolumn{2}{l}{ Number of } & Male Students Dropout & Total \\
\cline { 2 - 4 } & $1-3$ & $4-6$ & 7 and above & \\
Yes & 26 & 49 & 35 & 110 \\
No & 76 & 57 & 115 & 248 \\
Total & 102 & 106 & 150 & 358 \\
\hline
\end{tabular}

Source: Field survey, 2019

Chi-Square $=17.13 \quad$ P-Value $=0.000$

\section{Effect of Militancy on Male Students Drop out}

Table 3 shows the relationship between militancy and male understudies exiting in the review region. The chi-square worth is 17.13 and the p-esteem is 0.000 , which is extremely low at a .05 percent level, showing a solid relationship between the two factors. It shows that there is a solid relationship between aggressiveness and understudies' dropout in the review region.

Table 4: Effect of Militancy on Female Students Dropout in the Study Area

\begin{tabular}{lllll}
\hline Militancy & Number of Female Students Dropout & \multicolumn{2}{c}{ Total } \\
& $1-3$ & $4-6$ & 4 and above & 110 \\
\hline Yes & 66 & 40 & 29 & 248 \\
No & 48 & 171 & 3 & 358 \\
\hline Total & 114 & 211 & Chi-Square $=58.63$ p-value $=0.000$
\end{tabular}

\section{Effect of Militancy on Female Students Drop out}

Table 4 shows the relationship between militancy and female understudies dropping out in the review region. Where the Chi-Square worth is 58.63 and p-esteem is 0.000 , which is under 0.05 percent level, demonstrating a solid relationship between the two factors.

\section{Linear Regression Model and its Assumptions used in the Study}

Factual examinations depend on suppositions about the factors that will be inspected. The outcomes may not be solid in the event that specific presumptions are not met. Since it is absolutely impossible to decide whether the measurable tests' presumptions were met or not, not assessing the suspicions prompts issues in regards to the legitimacy of these models' decisions. 
Prior to deciphering the model's decision, different suspicions about numerous relapses should be tended to. Multicollinearity, heteroscedasticity, and ordinariness are the presumptions of (OLS) Odeneray Least Square (Jason, 2002).

Table 5: Variables: fitted values of Students Dropout

\begin{tabular}{ll}
\hline Chi2(1) & Prob > chi2 \\
\hline 1.11 & 0.2922 \\
\hline
\end{tabular}

\section{Estimation of Breusch-Pagan test to check the Heteroscedasticity for Student drop out}

Table 5 demonstrates the assessed worth of the Breusch-Pagan test to check the issue of heteroscedasticity and it is utilized for enormous example size. The outcome shows that the pesteem is more noteworthy than 0.05; thus we acknowledge the invalid theory of homoscedasticity; henceforth no rate of heteroscedasticity in the information.

Heteroscedasticity test Ho: There is no Heteroscedasticity (constant variance)

$\mathrm{H}_{1}$ : There is Heteroscedasticity (constant variance)

Table 6: Diagnostic test of normality (Shapiro-Wilk W test for normal data)

\begin{tabular}{lllcc}
\hline Variable & Observation & W & Z test & Probability \\
\hline $\begin{array}{l}\text { Standardized } \\
\begin{array}{l}\text { Residual for } \\
\text { Student drop out }\end{array}\end{array}$ & 358 & 0.99333 & 1.205 & 0.11419 \\
\hline
\end{tabular}

Source: Field Survey, 2019

\section{Shapiro-Wilk test for Normality}

Prior to assessing the impact of aggressiveness on understudies' dropout, it is important to check the ordinariness of the factors utilized in the relapse model. Shapiro-Wilk test has been utilized to check the ordinariness of the illustrative factors, which shows the conveyance of information of various factors (understudies quitter, the pay of family head, instruction, distance, family size, aggressiveness, early marriage, orientation of family head, family framework) are regularly appropriated or not.

The hypotheses for the test are

Hypotheses: $\mathrm{H}_{0}$ : Variable are not normally distributed

$\mathrm{H}_{1}$ : Variable are normally distributed

The p-value as shown in table 5, is greater than 0.05 ; hence we accept the alternative and reject the null hypothesis. The alternative hypothesis states that the data is normally distributed.

Table 7: VIF and Tolerance tests of Multicollinearity

\begin{tabular}{lll}
\hline Explanatory Variables of the Model & Tolerance & VIF \\
Income of Households ( Rs) & .826 & 1.210 \\
Education of Household Head (Year) & .888 & 1.126 \\
Distance of Respondent Home to Nearest School ( Km) & .825 & 1.213 \\
Family Size (Number) & .963 & 1.038 \\
Militancy (Dummy) & .761 & 1.314 \\
Early Marriage (Dummy) & .863 & 1.159 \\
Gender of Household Head (Dummy) & .886 & 1.129 \\
Family System (Dummy) & .788 & 1.269
\end{tabular}

Source: Field survey, 2019

\section{Diagnostic Test for Multicollinearity}

The aftereffects of the fluctuation expansion element and resistance tests for multicollinearity are displayed in Table 6. While resilience is the unaccounted-for level of variety in the autonomous variable, the other free factor, i.e., 1-R2, and difference expansion, is proportional to resistance. The difference expansion factor (VIF) upsides of all illustrative factors in this exploration study were under 5, showing that the recommended model doesn't disapprove of multicollinearity. 


\section{Standardized Residual to Estimate the Effect of Socio-economic Determinants on student dropout in the study area.}

Figure 1 shows the bell-shaped curve histogram, which indicates that the data is normally distributed.

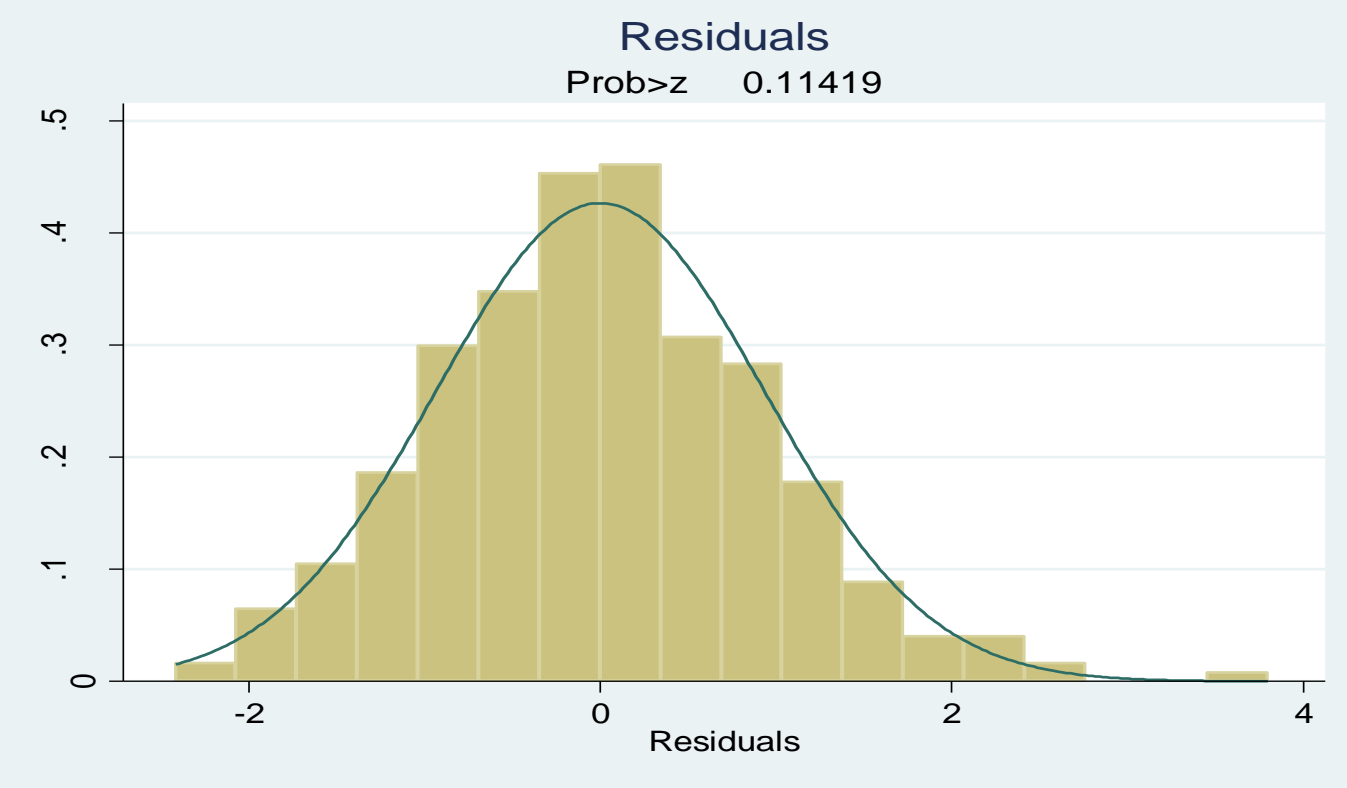

Figure 1. Histogram Shows Normal Distribution of Residuals

Table 8: Regression Analysis of Students Dropout form School

\begin{tabular}{|c|c|c|c|c|}
\hline \multirow{2}{*}{ Explanatory Variables } & \multicolumn{2}{|c|}{ Unstandardized Coefficients } & \multirow{2}{*}{$\mathrm{T}$} & \multirow{2}{*}{ Sig. } \\
\hline & $\beta$ & Standard Error & & \\
\hline (Constant) & 2.297 & .342 & 6.722 & .000 \\
\hline Income of Households & -6.161 & .000 & -8.991 & .000 \\
\hline Education of Household Head (in Years) & -.048 & .019 & -2.521 & .012 \\
\hline $\begin{array}{l}\text { Distance of Respondent Home to Nearest } \\
\text { School (in Km) }\end{array}$ & .184 & .070 & 2.635 & .009 \\
\hline Family Size (in Number) & .093 & .025 & 3.704 & .000 \\
\hline $\begin{array}{l}\text { Militancy } \\
\left(\mathrm{D}_{1}=1 \text {, household member dropout due to }\right. \\
\text { militancy, } 0 \text { otherwise })\end{array}$ & .508 & .124 & 4.092 & .000 \\
\hline $\begin{array}{l}\text { Early Marriage } \\
\left(\mathrm{D}_{2}=1 \text {, if member dropout from school due }\right. \\
\text { to E.M, } 0 \text { otherwise })\end{array}$ & .285 & .122 & 2.329 & .020 \\
\hline $\begin{array}{l}\text { Gender of Household Head }\left(\mathrm{D}_{3}=1 \text { male, }\right. \\
\text { 0,otherwise) }\end{array}$ & .039 & .138 & .287 & .774 \\
\hline $\begin{array}{l}\text { Family System } \\
\left(\mathrm{D}_{4}=\text { joint, } 0 \text { otherwise }\right)\end{array}$ & .271 & .123 & 2.211 & .028 \\
\hline $\mathrm{R}^{2}=0.435$ & & $=34.324$ & & \\
\hline
\end{tabular}

Multiple Regression Model was used to Estimate the Effect of Socio-Economic Determinants on Student Dropout in the Study Area

Table 8 exhibits the extended consequence of the numerous direct relapse model. The R2 esteem was 0.43 , which demonstrates that $43 \%$ of varieties in the reliant variable were explained by the logical factors contained in the model. The F measurement esteem was 34.32, which is bigger 
than the standard worth (0.05), which shows that the general model was critical, with a p-esteem (0.000).

Assessed Result of the Regression model of the understudies exiting with various factors. As indicated by the table, the coefficient of family head pay is - 6.16 and it is exceptionally huge (0.000) at a 5 percent importance level. The relationship shows that assuming different factors are kept consistent when one-rupee expansion in the pay of family head causes a diminishing in the quantity of understudy dropout by 6.16 . The outcomes demonstrated a negative connection between family pay and understudy dropout. The coefficient of family head's schooling is - .048, which is huge (0.012) at a 5 percent importance level. The outcome shows a negative connection between household's head education level and students drop out. A one-year expansion in family head training causes an abatement in the understudy dropout by 0.048 . The outcome shows that there is a negative connection between family head schooling and understudy dropout. The coefficient of distance from the closest school is 0.184 , which is critical at $5 \%$. The outcome shows a positive connection between understudy dropout and distance from home to the closest school, and it likewise shows that assuming the one-kilometer expansion in distance causes an increment in the understudy dropout by 0.184 . The outcome shows a positive connection between distance from the closest school and understudies drop out in the event that different factors are kept steady. The coefficient of Family Size is 0.093 , and it is critical at 5\%. The outcome shows a positive connection between understudy dropout and family size. On the off chance that different factors are kept consistent, when one party in the family size increment, the understudy dropout has expanded by 0.093 in the review region. The outcome shows that there is a positive connection between family size and understudy dropout rate. The assessed aftereffects of the table show the coefficient of early marriage, which is 0.285 . It is huge at $5 \%$. The outcome demonstrates a positive connection between early marriage and understudy dropout. It additionally shows that one-year expansions in the early marriage, understudies drop out has expanded by 0.285 . The outcome shows a positive connection between early marriage and understudy dropout in the review region. The coefficient of the orientation of the family head is 0.039 , which is huge at $5 \%$, it demonstrates that there is a positive connection between understudy dropout and orientation of the family heads. At the point when one individual of the male of the family head has expanded, the understudies drop out have expanded by 0.039 in the review region, assuming different factors stay consistent. The outcome likewise shows that there is a positive connection between the orientation of the family head and understudy dropout. The outcome shows that the coefficient of the family System is 0.271 , which is critical at 5\%. The outcome shows a positive connection between understudy dropout and the family framework. Assuming a family of the joint family framework expanded by one number reason 0.271 percent of progress will happen in understudy dropout in the review region. The outcome shows that there is a positive connection between the family framework and the understudy dropout. The assessed Result of the Regression model shows that the coefficient of aggressiveness is 0.508, which is profoundly huge at $5 \%$. In the event that different factors are kept consistent, militancy causes a 0.508 percent change in understudy dropout. The outcomes demonstrated that there is a positive connection between aggressiveness and understudy dropout.

As we have different illustrative factors in the model subsequently the normalized coefficient (Beta) showed the overall significance of every autonomous variable, it was seen that among every single logical variable, Militancy $(\mathrm{M})$ with a beta worth (0.508) highly affects subordinate variable which is the quantity of understudies' quitter and that was profoundly attractive. Any remaining factors i.e., pay, schooling, distance, family size, early marriage, and family framework were additionally found to have a critical relationship with the reliant variable rather than the orientation of the family head found to have an inconsequential relationship with the reliant variable is barred from the model during the examination. The accompanying outcomes are equivalent to the finding of Collins (2009) by Using numerous relapse examinations; it was 
resolved that aggressiveness, training of family head, family size, Distance from school, and family framework were the factors that are bound to foresee higher dropout rates among understudies. Moreover, unstandardized coefficients from the various relapse investigation uncovered that these autonomous factors enormously affected understudy dropout.

\section{Conclusions and Recommendations}

This concentrate on at long last inferred that to decide the impact of militancy and other financial determinants on understudies exited in District Mohmand. The Chi-square experimental outcome further demonstrates the relationship between various factors with understudy dropout in the review region. Results uncover that every one of the factors like hostility, pay, early relationships, family size, distance, training, and the family framework had a profoundly critical and positive relationship with the understudies exiting in the review region. Numerous straight relapse model (MLRM) was utilized to examine the relationship between subordinate variable i.e., understudies' dropout, and informative factors i.e., hostility, the pay of family head, instruction of family head, the distance of respondents from home to the closest school, family size, early relationships, the orientation of the family head and family framework. It was seen that every one of the illustrative factors was found with a huge positive relationship aside from pay and Education of family head. Unstandardized coefficient esteems show that the greatest impact on understudy dropout was seen on account of militancy.

- Educational institutes should be provided with strong security to assure the safety of students.

- More budget should be allocated to the education sector to meet the demand for quality education.

- To encourage female students, needy students should be provided with scholarships and financial aid.

- Promote gender equality and female education through an awareness campaign in the light of the Holy Quran and Sunnah.

- The government should take steps to ensure that education services are available during times of conflict and disaster so that an individual's education is not disrupted.

\section{References}

Naqvi, A. A., Khan, S. Z., \& Ahmad, Z. (2012). The impact of militancy on education in FATA. TIGAH: A Journal of Peace and Development, 2(1), 22-40.

Cassese, A. (2006). The multifaceted criminal notion of terrorism in international law. Journal of International Criminal Justice, 4(5), 933-958.

Christle, C. A., Jolivette, K., \& Nelson, C. M. (2007). School characteristics related to high school dropout rates. Remedial and Special education, 28(6), 325-339.

Collins, D. B. (2009). Variables that impact high-school dropout rates in a large metropolitan area (Doctoral dissertation, University of Georgia).

Maxwell, S., Urey, I., \& Ashley, C. (2001). Emerging issues in rural development. London: Overseas Development Institute.

Osborne, J. W. (2002). Effect sizes and the disattenuation of correlation and regression coefficients: lessons from educational psychology. Practical Assessment, Research, and Evaluation, 8(1), 11.

Rizvi, H. A. (2005). Theoretical formulations on Terrorism. Global Terrorism, genesis, implications, remedial and counterterrorism. Islamabad: Institute of Regional Studies.

Riaz, A. (2012). Islamist militancy in Bangladesh: A complex web. Routledge.

Hyder, S., \& Akram, N. (2015). Ihtsham ul Haq Padda.". Impact of Terrorism on Economic Development in Pakistan." Pakistan Business Review, 16, 704-22.

Saqib, M., \& Ahmad, S. M. (2014). Root causes of low female literacy in FATA Pakistan:(a case study of Jalozai camp). International Journal of Academic Research in Business and Social Sciences, 4(3), 457. 
Ullah, A., \& Muhammad, N. (2020). Prevalence of mental health problems among youth involved in street crimes. Rawal Medical Journal, 45(4), 938-942.

Umoh, S. H. (1986). Comparative study of perceptions of school drop-out by principals and students in selected secondary schools in Kwara, Cross River and Rivers States. The Nigerian Journal of Guidance \& Counselling.

Andreotti, V., \& de Souza, L. M. T. M. (2008). Learning to read the world: Through other eyes. Global Education.

Yamane, T. (1967). Problems to accompany" Statistics, an introductory analysis". Harper \& Row. 